\section{Preliminary Findings on the Correlation between Water-soluble Carbohydrate Content in Stolons and First Year Green-up of Seeded Bermudagrass Cultivars}

\author{
Stefano Macolino ${ }^{1}$, Matteo Serena ${ }^{1}$, Bernd Leinauer ${ }^{2,3}$, \\ and Umberto Ziliotto ${ }^{1}$
}

ADDITIONAL INDEX wORDs. Cynodon dactylon, sigmoidal model, stolon, sugar, warm-season turfgrass

Summary. Warm-season grasses are not widely accepted in Mediterranean countries because they lose color during the winter months. A study was conducted at the University of Padova (Padova, Italy) to determine whether fall and spring watersoluble carbohydrate (WSC) content in stolons of seeded bermudagrass cultivars (Cynodon dactylon) influenced spring green-up in the first year of establishment. Nine bermudagrass cultivars (La Paloma, Mohawk, NuMex Sahara, Princess 77, Riviera, SR 9554, Barbados, Contessa, and Yukon) were seeded in July 2005, and dry weight and WSC content in stolons were measured in Fall 2005 and again in Spring 2006. The percentage of green cover and days needed to achieve $80 \%$ green cover (D80) were regressed against November and March values of stolon dry weight and WSC content to determine if they were good predictors of D80. 'Yukon' showed earliest spring green-up by end of April, and 'Princess 77' and 'Riviera' were slowest, needing 43 to 46 days more than 'Yukon' to reach D80. There was a significant inverse relationship between November $\left(r^{2}=0.57\right)$ and March $\left(r^{2}=0.77\right)$ WSC content in stolons and D80 for all nine bermudagrass cultivars. These results suggest that bermudagrass cultivars with high WSC in stolons recover more rapidly from dormancy during establishment than those with low WSC content.

$\mathrm{M}$ aintaining cool-season grasses in temperate or transitional climate zones has been criticized because of the relatively high irrigation requirements during the summer. As a result, the use of warm-season turf species that require less water than cool-season grasses is encouraged in Mediterranean countries in an effort to reduce water consumption for landscape irrigation. Unlike cool-season grasses, warmseason species such as bermudagrass are cold sensitive and will lose color when dormant during the cooler periods of the year. Although warmseason turf may not provide active growth and green color year round, they can be used successfully in transitional climate zones, even when dormant (Anderson et al., 2007; Patton et al., 2008). However, a winter dormancy period that prevents year-round green color is currently the main

${ }^{1}$ Department of Environmental Agronomy and Crop Production, University of Padova, viale dell'Università 16, Agripolis 35020, Legnaro, Padova, Italy

${ }^{2}$ Department of Extension Plant Sciences, New Mexico State University, Las Cruces, NM 88003

${ }^{3}$ Corresponding author. E-mail: leinauer@nmsu.edu. impediment to a more widespread use of warm-season grasses in these transition zones.

Bermudagrass is one of the warmseason turf species that is best suited to transitional zones in Europe (Croce et al., 2004). Over the last few years it has become more widely used in Italy and is grown on athletic fields, parks, and lawns. While athletic turf areas are usually overseeded with cool-season grasses such as perennial ryegrass (Lolium perenne) or annual ryegrass (Lolium multiflorium) during the fall to provide green cover during winter months (Gaetani et al., 2004, 2007;
Schmidt and Shoulders, 1980), areas that are primarily used during the warmer periods can be managed without overseeding. Winterhardiness and early spring green-up are considered the most important factors in selecting bermudagrass cultivars in transitional zones (Patton et al., 2008; Richardson et al., 2004).

Numerous studies have reported on the significant role of carbohydrates in turfgrass stress tolerance. White (1973) described two major carbohydrate groups in plants, the nonstructural and the structural carbohydrates. Nonstructural carbohydrates include all major reserve constituents such as reducing sugars (glucose and fructose), non-reducing sugars (sucrose), fructosans, and starches. Hemicellulose (pentosans and hexosans) and cellulose are considered structural carbohydrates and do not provide significant reserves (White, 1973). Most of the nonstructural carbohydrates [also referred to as total nonstructural carbohydrates (TNC)] are water-soluble saccharides, but also include larger polysaccharides (starches) that are insoluble in water. Therefore, water-soluble carbohydrates (WSC), or water soluble non-structural carbohydrates represent a subgroup of TNC.

A positive correlation has been reported between TNC and freezing tolerance in turfgrasses (Di Paola and Beard, 1992; Fry et al., 1993; Rogers et al., 1975). Carbohydrates are stored inside the plant during fall when growth and metabolism are slow, which in return improves cold hardiness by reducing the freezing point and delaying or avoiding cell freezing (Stier and Fei, 2008). In the spring, the carbohydrates are used as an energy source to support the renewed shoot growth (Di Paola and Beard, 1992; Rogers et al., 1975).

\begin{tabular}{llll}
\hline $\begin{array}{l}\text { Units } \\
\begin{array}{l}\text { To convert U.S. to SI, } \\
\text { multiply by }\end{array}\end{array}$ & U.S. unit & SI unit & $\begin{array}{l}\text { To convert SI to U.S., } \\
\text { multiply by }\end{array}$ \\
\hline 0.3048 & $\mathrm{Ft}$ & $\mathrm{m}$ & 3.2808 \\
0.0929 & $\mathrm{ft}^{2}$ & $\mathrm{~m}^{2}$ & 10.7639 \\
2.54 & inch $(\mathrm{es})$ & $\mathrm{cm}$ & 0.3937 \\
25.4 & inch $(\mathrm{es})$ & $\mathrm{mm}$ & 0.0394 \\
1.1209 & $\mathrm{lb} / \mathrm{acre}$ & $\mathrm{kg} \cdot \mathrm{ha}^{-1}$ & 0.8922 \\
305.1517 & $\mathrm{Oz} / \mathrm{ft}^{2}$ & $\mathrm{~g} \cdot \mathrm{m}^{-2}$ & 0.0033 \\
62.5000 & $\mathrm{Oz} / \mathrm{lb}$ & $\mathrm{g} \cdot \mathrm{kg}^{-1}$ & 0.0160 \\
6.2500 & $\mathrm{Oz} / \mathrm{lb}$ & $\mathrm{g} / 100 \mathrm{~g}$ & 0.1600 \\
1 & $\mathrm{ppm}$ & $\mathrm{mg} \cdot \mathrm{kg}^{-1}$ & 1 \\
$\left({ }^{\circ} \mathrm{F}-32\right) \div 1.8$ & ${ }^{\circ} \mathrm{F}$ & ${ }^{\circ} \mathrm{C}$ & $\left(1.8 \times{ }^{\circ} \mathrm{C}\right)+32$
\end{tabular}


Differences in cold hardiness among species depend mostly on plant metabolism during the autumn months, which in turn affects TNC accumulation in storage organs. Unlike bermudagrass, cold tolerance in zoysiagrass (Zoysia japonica) has been attributed to an increased photosynthetic rate during the cold hardening period (Rogers et al., 1977). However, Dionne et al. (2001) observed that low temperature tolerance in cool-season annual bluegrass ecotypes was not correlated to sugar levels of sucrose and fructan. Similarly, freezing tolerance of warmseason st. augstinegrass (Stenotaphrum secundatum) could also not be correlated with TNC content (Fry et al., 1991; Maier et al., 1994).

Rhizomes and stolons are the principal locations of carbohydrate storage in well-established bermudagrass (Dunn and Nelson, 1974). In comparing the relative importance of the two organs, Dunn and Nelson (1974) suggested that carbohydrate content in stolons was more important to the winter survival of these grasses than the content in rhizomes. In a later study, however, Dunn et al. (1980) reported a strong positive correlation between carbohydrate content in rhizomes of 20 mature bermudagrass cultivars and the speed of spring green-up, an indicator of successful winter survival. In contrast, Goatley et al. (1994) reported that while fertility had an effect on spring green-up of mature Tifgreen turf, no correlation between carbohydrate (TNC) content in rhizomes and spring greenup was observed. Munshaw et al. (2006) and White and Schmidt (1990) documented the importance of management practices such as late season fertilization on fall color retention, cold tolerance, and spring recovery of bermudagrass.

All of these studies were conducted on mature bermudagrass, and information is lacking on the role of carbohydrates in the timing and speed of spring green-up during spring after establishment. Although the presence of rhizomes in bermudagrass at the end of the first growing period have been reported (Ahring et al., 1975; Trenholm et al., 1998), more recent studies (Hensler et al., 1999; Munshaw et al., 2001; Richardson et al., 2004, 2005) have all concluded that seeded bermudagrass do not produce rhizomes during the establishment year. These results concur with our preliminary observations that no rhizomes were produced during the first year of establishment, and suggest that carbohydrates in stolons may play an important role in winter survival and early green-up of newly established bermudagrass. Munshaw et al. (2001) showed a positive correlation between total nitrogen applied to 'Mirage' bermudagrass during establishment and TNC in stolons at the end of the first growing season. The plots were unaffected by winter kill, confirming the importance of TNC in winter survival, but no timing or rate of spring greenup was reported. Early green-up is not only important to ensure successful winter survival of bermudagrass (Ahring et al., 1975), but it also reflects a shorter dormancy period, a feature that would help this grass gain greater market acceptance in transition zones. Numerous studies have investigated the role of nonstructural carbohydrates on cold or freeze tolerance and on fall or spring color (e.g., Dunn et al., 1980; Dunn and Nelson, 1974; Goatley et al., 1994, 1998, 2005; Miller and Dickens, 1996; Munshaw et al., 2001, 2006; Pedreira et al., 2000; Trenholm et al., 1998), and few report on the specific role of WSC content in cold and freeze tolerance and in bermudagrass color in fall and spring (Dunn and Nelson, 1974; Dunn et al., 1980; White and Schmidt, 1989; Zhang et al., 2006). No published studies exist on the importance of
WSC on spring recovery in newly seeded bermudagrass.

To address the gap in knowledge about the role of stolon WSC reserves in regrowth and greening of seeded bermudagrass during and after the first growing season, a study was conducted at the University of Padova (upper transition zone, northern Italy). The objectives of the study were to examine the seasonal trend in WSC content in stolons of seeded bermudagrass during the first year of establishment and during spring after the first winter, and to determine whether the timing of spring green-up and recovery from winter stress was affected by WSC in stolons.

\section{Materials and methods}

A field experiment was conducted at the Experimental Farm of Padova University from Nov. 2005 to July 2006 to examine the change in carbohydrate content in stolons of seeded bermudagrass cultivars in response to seasonal variation in temperature of northeastern Italy (similar to U.S. Department of Agriculture plant hardiness zone 8 ). The climate in the area is considered subcontinental with an annual mean temperature of $12.3^{\circ} \mathrm{C}$ and average minimum and maximum temperatures of -5.5 and $32.8^{\circ} \mathrm{C}$. The average annual rainfall is $811 \mathrm{~mm}$ and is mostly distributed during the growing season from April to November. Climate data during the investigative period were collected at a weather station in close proximity to the research area (Table 1). Plots

Table 1. Monthly average maximum and minimum air temperature, soil temperature at $100 \mathrm{~mm}$ (3.94 inches) depth, and monthly precipitation at the University of Padova research station in Legnaro, Italy, from July 2005 through June 2006.

\begin{tabular}{|c|c|c|c|c|}
\hline \multirow[b]{2}{*}{ Month } & \multicolumn{2}{|c|}{ Air temp $\left({ }^{\circ} \mathrm{C}\right)^{\mathrm{z}}$} & \multirow{2}{*}{$\begin{array}{c}\text { Soil } \\
\text { temp }\left({ }^{\circ} \mathrm{C}\right)\end{array}$} & \multirow{2}{*}{$\begin{array}{c}\text { Precipitation } \\
\quad(\mathrm{mm})^{\mathrm{z}}\end{array}$} \\
\hline & Maximum & Minimum & & \\
\hline July 2005 & 29.3 & 18.3 & 23.3 & 66.6 \\
\hline Aug. 2005 & 26.3 & 16.2 & 21.4 & 241.0 \\
\hline Sept. 2005 & 25.0 & 15.1 & 19.7 & 71.8 \\
\hline Oct. 2005 & 17.7 & 10.7 & 14.2 & 181.0 \\
\hline Nov. 2005 & 11.4 & 5.2 & 7.4 & 142.8 \\
\hline Dec. 2005 & 6.8 & 0.0 & 2.2 & 49.4 \\
\hline Jan. 2006 & 5.8 & -1.2 & 1.6 & 30.8 \\
\hline Feb. 2006 & 8.8 & 0.5 & 3.4 & 33.2 \\
\hline Mar. 2006 & 12.1 & 3.5 & 6.8 & 44.4 \\
\hline Apr. 2006 & 17.9 & 8.2 & 11.8 & 41.6 \\
\hline May 2006 & 22.2 & 11.9 & 16.5 & 92.4 \\
\hline June 2006 & 27.1 & 15.7 & 21.3 & 14.6 \\
\hline
\end{tabular}

${ }^{\mathrm{z}}\left(1.8 \times{ }^{\circ} \mathrm{C}\right)+32={ }^{\circ} \mathrm{F}, 1 \mathrm{~mm}=0.0394$ inch. 
were seeded on 4 July 2005 with bermudagrass cultivars Princess 77, Mohawk, NuMex Sahara, Barbados, Contessa, Riviera, Yukon, La Paloma, and SR 9554. Cultivars were seeded at a rate of $4 \mathrm{~g} \cdot \mathrm{m}^{-2}$ pure live seed on a silty loam. The soil at the site had a $\mathrm{pH}$ of 8.1 , an organic matter content of $2.3 \%$, a total nitrogen content of $0.13 \mathrm{~g} / 100 \mathrm{~g}$ soil, an available phosphorus content of $38.3 \mathrm{mg} \cdot \mathrm{kg}^{-1}$ soil, and an exchangeable potassium content of $178.1 \mathrm{mg} \cdot \mathrm{kg}^{-1}$ soil.

Slow-release fertilizer $(20 \mathrm{~N}-$ $2.2 \mathrm{P}-6.6 \mathrm{~K}$ ) was applied twice in 2005 (August and September) and twice in 2006 (April and June) at a rate of $40 \mathrm{~kg} \cdot \mathrm{ha}^{-1}$. During the growing period, plots were mowed weekly with a rotary mower at a height of $27 \mathrm{~mm}$. Supplemental irrigation from a sprinkler system was provided only during the first month of the establishment period. The experimental design was a randomized complete block with four replications and a plot size of $7.2 \mathrm{~m}^{2}(1.6 \mathrm{~m} \times 4.5 \mathrm{~m})$.

In Nov. 2005 and Mar., May, and July 2006, turf samples measuring $20 \mathrm{~cm}$ (length) $\times 20 \mathrm{~cm}$ (width) $\times$ $4 \mathrm{~cm}$ (depth) were randomly collected from each plot to measure stolon development and WSC in the stolons. Turf samples were washed to remove any soil from the vegetative parts, and stolons were removed from the plugs with scissors and were immediately frozen at $-22{ }^{\circ} \mathrm{C}$. The stolons were later freeze-dried and weighed using an analytical balance to determine stolon dry weight in grams per square meter. Water-soluble carbohydrates were then extracted from dried and ground tissue using an $80 \%$ ethanol solution followed by a hot water extraction (Suzuki, 1968). Carbohydrates were colorimetrically quantified after reacting with anthrone reagent (Thomas, 1977).

Spring green-up was determined weekly from 1 Apr. to 22 June 2006 by visually assessing the percentage of green color of each plot. A sigmoidal model (GraphPad Prism 5.0 for Windows; GraphPad Software, La Jolla, CA) was used to calculate days of year (beginning 1 Jan. 2006) needed by each plot to reach $80 \%$ green color (D80). Stolon dry weight, WSC data, spring green-up, and D80 were subsequently subjected to analysis of variances using SAS Proc Mixed (version 9.2; SAS Institute, Cary, NC) followed by Fisher's protected least significant difference test to identify significant differences between means. November and March values of stolon dry weight and WSC were regressed against D80 to determine whether the speed of spring green-up could be predicted from stolon dry weight or WSC in fall and spring.

\section{Results and discussion}

STOLON DRY WEIGHT. The data analysis revealed significant sampling date $\times$ grasses interactions $(P<0.001)$. Data were subsequently analyzed separately for all sampling dates. Stolon dry weight of 'La Paloma', 'Princess 77', 'Riviera', 'SR 9554', 'Barbados', and 'Yukon' plots decreased between Nov. 2005 and Mar. 2006, and continued to decrease for 'Princess 77' and 'Barbados' plots until May (Fig. 1). Compared with other bermudagrass cultivars, Yukon was earliest to significantly increase stolon weight (March-May) (Fig. 1). Stolon dry weight in all other cultivars increased later, from May to July. When data were averaged for all cultivars, stolon dry weight quadrupled from 142 to $600 \mathrm{~g} \cdot \mathrm{m}^{-2}$ between May and July 2006. Of all cultivars tested, 'Barbados' showed the greatest spring increase in stolon dry weight (Fig. 1).

WSC CONTENT. A significant interaction effect between sampling date and turfgrasses' WSC was detected $(P<0.001)$, thus, data were analyzed separately for all sampling dates. Figure 2 shows changes in WSC from
Nov. 2005 to July 2006. WSC did not change during the winter months (Nov. 2005-Mar. 2006) for ' $\mathrm{La}$ Paloma', 'Mohawk', 'SR 9554', or 'Yukon'. During the same period, WSC decreased in 'NuMex Sahara', 'Riviera', and 'Barbados', and increased in 'Contessa'. During Spring 2006 (March-May) WSC decreased sharply in 'Barbados', 'Contessa', and 'Yukon', but increased in 'NuMex Sahara'. WSC in all other bermudagrass cultivars remained constant from Mar. to May 2006 (Fig. 2). During early summer (May-July 2006), WSC also increased in 'Princess 77', 'Riviera', 'Barbados', 'Contessa', and 'Yukon', and all cultivars tested had accumulated equal amounts of WSC in their stolons (Fig. 2). The high content of WSC observed in most species in November can be attributed to a reduction in grass growth that is accompanied by an accumulation of carbohydrates when the plants' metabolism is still active. These findings support those of Dunn and Nelson (1974) and Trenholm et al. (1998) who found increased fall levels of total carbohydrates and sucrose in 'Midway' and 'U3' bermudagrass cultivars (Dunn and Nelson, 1974) and of TNC in 'FloraDwarf' bermudagrass (Trenholm et al., 1998). Zhang et al. (2006) also reported TNC accumulation in 'Riviera' and 'Princess 77' bermudagrasses after cold acclimation. Similarly, the depletion of carbohydrates during early spring is associated with the utilization of carbohydrate as an energy source to

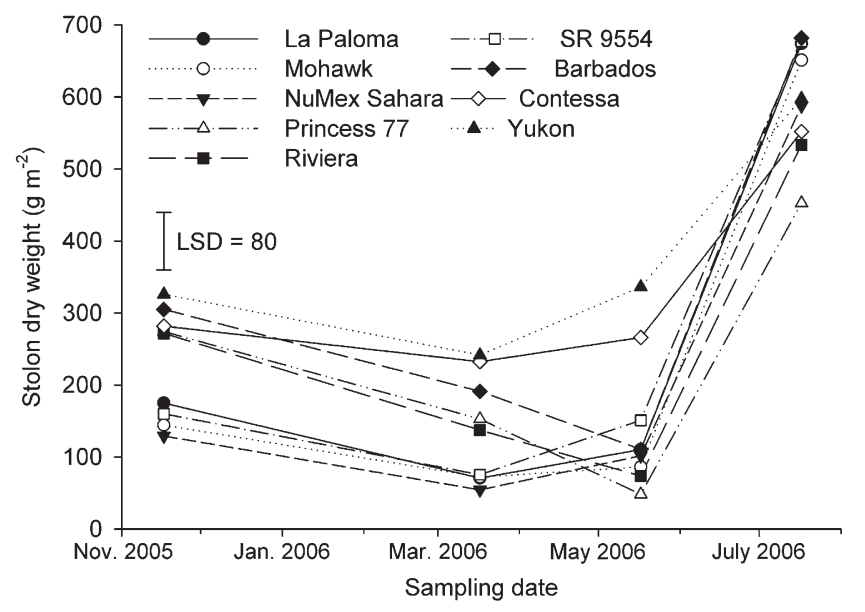

Fig. 1. Stolon dry weight of nine bermudagrass cultivars as affected by sampling date. Data points represent an average of four replicates. Error bar in the top left corner of the graph shows Fisher's protected least significant difference at $\alpha=0.05$ (LSD) and can be used to determine significant differences between grasses and sampling dates; $1 \mathrm{~g} \cdot \mathrm{m}^{-2}=0.0033 \mathrm{oz} / \mathrm{ft}^{2}$. 


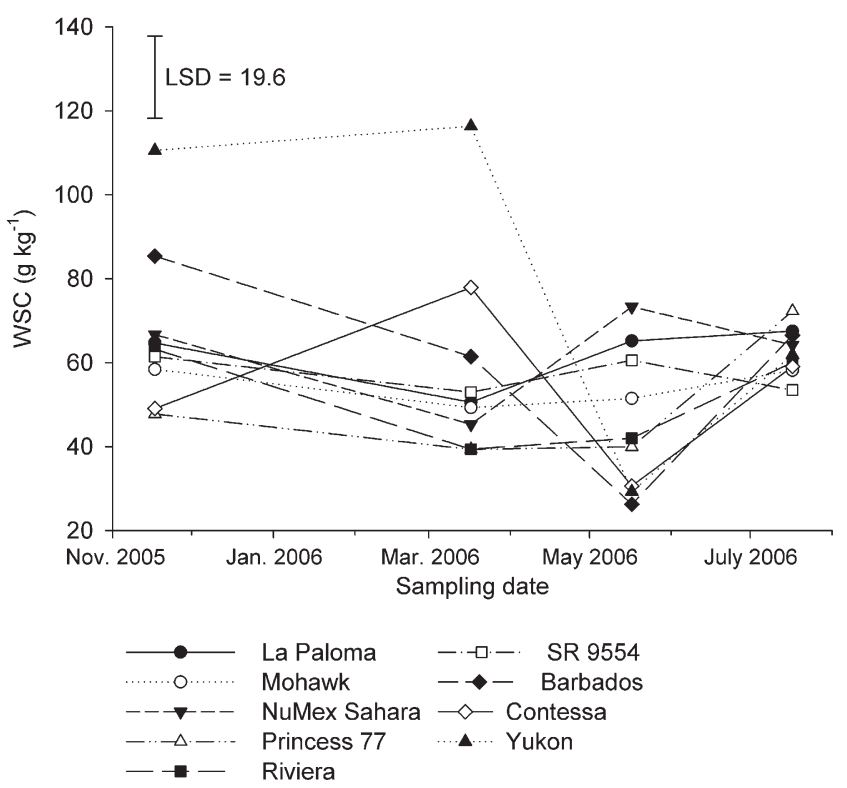

Fig. 2. Water-soluble carbohydrate content in stolons of nine bermudagrass cultivars as affected by sampling date. Data points represent an average of four replicates. Error bar in the top left corner of the graph shows Fisher's protected least significant difference at $\alpha=\mathbf{0 . 0 5}$ (LSD) and can be used to determine significant differences between grasses and sampling dates; $1 \mathrm{~g} \cdot \mathrm{kg}^{-1}=0.0160 \mathrm{oz} / \mathrm{lb}$.

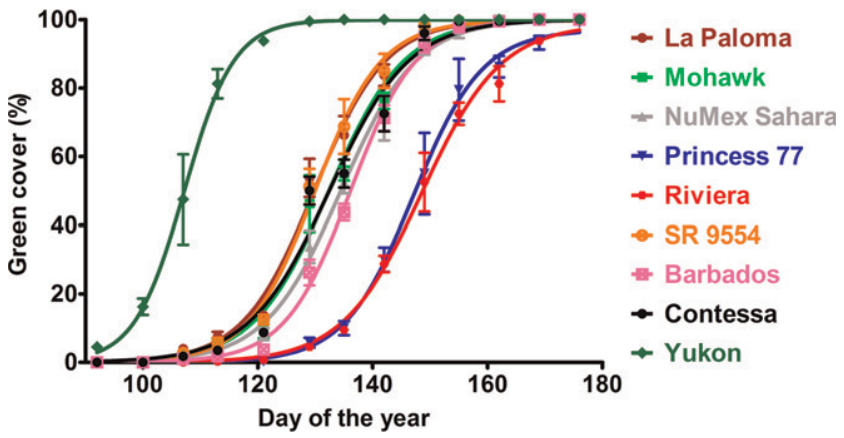

Fig. 3. Green cover based on visually assessing the plots' green cover of nine bermudagrass cultivars (La Paloma, Mohawk, NuMex Sahara, Princess 77, Riviera, SR 9554, Barbados, Contessa, and Yukon) as affected by day of the year in 2006. Data points represent an average of four replicates and error bars indicate SE.

Table 2. Number of days (starting 1 Jan. 2006) to reach $80 \%$ green cover [D80 (assessed visually and based on sigmoidal model estimates)] for nine bermudagrasses.

\begin{tabular}{lc}
\hline Cultivar & D80 (d) \\
\hline Barbados & $145 \mathrm{~b}^{\mathrm{z}}$ \\
Contessa & $143 \mathrm{bc}$ \\
La Paloma & $139 \mathrm{c}$ \\
Mohawk & $142 \mathrm{bc}$ \\
NuMex Sahara & $145 \mathrm{~b}$ \\
Princess 77 & $156 \mathrm{a}$ \\
Riviera & $159 \mathrm{a}$ \\
SR 9554 & $139 \mathrm{c}$ \\
Yukon & $113 \mathrm{~d}$ \\
\hline
\end{tabular}

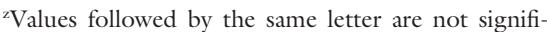
cantly different from one another via Fisher's protected least significant difference at $\alpha=0.05$. support spring green-up and growth (Rogers et al., 1975). The increase of carbohydrate content observed in early summer can be attributed to photosynthesis in new leaves (Fig. 2). Differences in WSC among bermudagrass cultivars occurred at the end of the winter months, with 'Yukon' exhibiting the highest values in March coinciding with highest stolon dry weight in 'Yukon' and 'Contessa'. Dunn and Nelson (1974) also reported differences in fall and winter stolon dry weight between bermudagrass cultivars and concluded better winter survival for cultivars with higher stolon weight. In March, carbohydrate concentration in 'Yukon' was more than double than that of 'La Paloma', 'Mohawk', 'NuMex Sahara', 'Princess 77', 'Riviera', 'SR 9554', and 'Barbados'. 'La Paloma' and 'NuMex Sahara' depleted their carbohydrate reserves to their lowest levels in March, while 'Barbados', 'Contessa', and 'Yukon' exhibited lowest WSC content in May.

SPRING GREEN-UP. 'Yukon' (group 1) showed earliest green-up (Fig. 3 ) and reached $80 \%$ green cover by end of April (Table 2). 'Mohawk', 'La Paloma', 'NuMex Sahara', 'SR 9554', 'Barbados', and 'Contessa' reached $80 \%$ green cover by midMay (Table 2). Last, 'Riviera' and 'Princess 77' showed the slowest greening (Fig. 3) and needed over $40 \mathrm{~d}$ longer to reach $80 \%$ green cover than Yukon (Table 2). These spring green-up results are in part confirmed by the National Turfgrass Evaluation Program's (NTEP) 2002 bermudagrass trial (NTEP, 2009). From a total of 20 test locations across the continental United States, three reported that 'Yukon' was the earliest to achieve green-up, followed by 'Riviera' and then 'Princess 77' during spring after establishment. However, in this trial there was no difference in green-up between 'Riviera' and 'Princess 77'. These results, equal green-up after establishment between 'Riviera' and 'Princess 77', have been reported by three locations in the NTEP trial (NTEP, 2009).

Predicting green-UP from STOLON DRY WEIGHT AND WSC. The regression analysis revealed that neither November $(P=0.735)$ nor March $(P=0.414)$ stolon dry weight values were significant predictors of D80. However, November $(P=0.018)$ and March $(P=0.002)$ WSC values were significant predictors of D80 with regression coefficients of 0.57 and 0.77 , respectively. These results demonstrate the equal importance of fall and spring WSC for early spring green-up in bermudagrass after establishment, and show that cultivars with highest WSC concentrations in fall and spring recovered more rapidly from dormancy than those with low concentrations.

\section{Conclusion}

These results demonstrate that bermudagrasses with the highest winter concentrations of WSC in stolons showed the earliest spring green-up. 
Thus, to achieve short dormancy periods and rapid spring green-up, cultivars need to be developed that promote storage and maintenance of large amounts of WSC until the end of winter. Furthermore, fall fertilization and other maintenance strategies that promote WSC storage during hardening-off periods and that help maintain high levels until the end of winter should be developed. More research is needed to determine the effect of different climatic conditions on WSC storage and early spring green-up. These results also demonstrate the need for additional longerterm research on the importance of WSC in early spring green-up of bermudagrass. Our study focused on WSC in stolons in the first year of establishment, but further research is needed to determine if fall WSC concentrations in stolons and rhizomes of mature grasses have a similar effect on spring green-up.

\section{Literature cited}

Ahring, R.M., W.W. Huffine, C.M. Taliaferro, and R.D. Morrison. 1975. Stand establishment of bermudagrass from seed. Agron. J. 67:229-232.

Anderson, J.A., C.M. Taliaferro, and Y.Q. Wu. 2007. Freeze tolerance of seed- and vegetatively propagated bermudagrasses compared with standard cultivars. Appl. Turfgrass Sci. 10.1094/ATS-20070508-01-RS.

Croce, P., A. De Luca, M. Mocioni, M. Volterrani, and J.B. Beard. 2004. Adaptability of warm season turfgrass species and cultivars in a Mediterranean climate. Acta Hort. 661:365-368.

Dionne, J., Y. Castonguay, P. Nadeau, and Y. Desjardins. 2001. Freezing tolerance and carbohydrate changes during cold acclimation of green-type annual bluegrass (Poa annua L.) ecotypes. Crop Sci. 41:443-451.

Di Paola, J.M. and J.B. Beard. 1992. Physiological effects of temperature stress, p. 231-267. In: D.V. Waddington, R.N. Carrow, and R.C. Shermann (eds.). Turfgrass. Amer. Soc. Agron., Crop Sci. Soc. Amer., Soil Sci. Soc. Amer., Madison, WI

Dunn, J.H. and C.J. Nelson. 1974. Chemical changes occurring in three bermudagrass turf cultivars in relation to cold hardiness. Agron. J. 66:28-31.

Dunn, J.H., C.J. Nelson, and J.L. Sebaugh. 1980. Characterization of thatch, rhizomes, carbohydrates, and spring deadspot in twenty cultivars of bermudagrass. J. Amer. Soc. Hort. Sci. 105:653-657.

Fry, J.D., N.S. Lang, and R.G.P. Clifton. 1991. Freezing resistance and carbohydrate composition of 'Floratum' st. augustinegrass. HortScience 26:15371539.

Fry, J.D., N.S. Lang, G.P. Clifton, and F.P. Maier. 1993. Freezing tolerance and carbohydrate content of low-temperatureacclimated and nonacclimated centipedegrass. Crop Sci. 33:1051-1055.

Gaetani, M., M. Volterrani, N. Grossi, F. Lulli, and S. Magni. 2007. Bermudagrass overseeding with perennial ryegrass: A comparison of different spring management programs. Proc. Atti XXXVII Convegno della Società Italiana di Agronomia, 13-14 Sept. 2007, Catania, Italy. p. 105106.

Gaetani, M., S. Magni, S. Miele, and M. Volterrani. 2004. Bermudagrass autumn overseeding with annual ryegrass. Acta Hort. 661:353-356.

Goatley J.M., Jr., V. Maddox, D.J. Lang, and K.K. Crouse. 1994. 'Tifgreen' bermudagrass response to late-season application of nitrogen and potassium. Agron. J. 86:7-10.

Goatley, J.M., V.L. Maddox, and K.L. Hensler. 1998. Late-season applications of various nitrogen sources affect color and carbohydrate content of 'Tiflawn' and Arizona common bermudagrass. HortScience 33:692-695.

Goatley, J.M., V.L. Maddox, D.L. Lang, R.E. Elmore, and B.R. Stewart. 2005. Temporary covers maintain fall bermudagrass quality, enhance spring greenup, and increase stem carbohydrate levels. HortScience 40:227-231.

Hensler, K.L., M.D. Richardson, and J.R. Bailey. 1999. Implications of seeded bermudagrass planting date and morphology on cold tolerance, p. 69-71. In: J.R. Clark and M.D. Richardson (eds.). Horticultural studies 1998 (Res. Ser. 466). Arkansas Agr. Expt. Sta., Univ. of Arkansas, Div. Agr., Fayetteville.

Maier, F.P., N.S. Lang, and J.D. Fry. 1994. Freezing tolerance of three st. augustinegrass cultivars as affected by stolon carbohydrate and water content. J. Amer. Soc. Hort. Sci. 119:473-476.

Miller, G.L. and R. Dickens. 1996. Bermudagrass carbohydrate levels as influenced by potassium fertilization and cultivar. Crop Sci. 36:1283-1289.

Munshaw, G.C., E.H. Ervin, C. Shang, S.D. Askew, X. Zhang, and R.W. Lemus.
2006. Influence of late-season iron, nitrogen, and seaweed extract on fall color retention and cold tolerance of four bermudagrass cultivars. Crop Sci. 46:273283.

Munshaw, G.C., D.W. Williams, and P.L. Cornelius. 2001. Management strategies during the establishment year enhance production and fitness of seeded bermudagrass stolons. Crop Sci. 41:1558-1564.

National Turfgrass Evaluation Program. 2009. 2002 National bermudagrass test: 2003-06 data. 6 Sept. 2009. <http:// www.ntep.org/data/bg02/bg02_04-1/ bg0204t10b.txt>.

Patton, A.J., M.D. Richardson, D.E. Karcher, J.W. Boyd, Z.J. Reicher, J.D. Fry, J.S. McElroy, and G.C. Munshaw. 2008. A guide to establishing seeded bermudagrass in the transition zone. Appl. Turfgrass Sci. 10.1094/ATS2008-0122-01-MD.

Pedreira, C.G.S., L.E. Sollenberger, and P. Mislevy. 2000. Botanical composition, light interception, and carbohydrate reserve status of grazed 'Florakirk' bermudagrass. Agron. J. 92:194-199.

Richardson, M.D., D.E. Karcher, and J.W. Boyd. 2005. Winter survival of seeded bermudagrass: The recent development of high-quality seeded bermudagrasses makes the choice of this species for fairways even more appealing. U.S. Golf Assn. Green Section Record 43:15-18.

Richardson, M.D., D.E. Karcher, P. Berger, and J.W. Boyd. 2004. Utilizing improved seeded bermudagrasses on transition-zone sports fields. Acta Hort. 661:369-374.

Rogers, R.A., J.H. Dunn, and C.J. Nelson. 1975. Cold hardening and carbohydrate composition of 'Meyer' zoysia. Agron. J. 67:836-838.

Rogers, R.A., J.H. Dunn, and C.J. Nelson. 1977. Photosynthesis and cold hardening in zoysia and bermudagrass. Crop Sci. 17: 727-732.

Schmidt, R.E. and J.F. Shoulders. 1980. Seasonal performance of selected temperate turfgrasses overseeded on bermudagrass turf for winter sports. Intl. Turfgrass Soc. Res. J. 3:75-86.

Stier, J.C. and S.Z. Fei. 2008. Cold stress physiology and management of turfgrasses, p. 473-505. In: M. Pessarakli (ed.). Handbook of turfgrass management and physiology. CRC Press, Boca Raton, FL.

Suzuki, M. 1968. Fructosan in the timothy haplocorm. Can. J. Bot. 46:1201-1206. 
Thomas, T.A. 1977. An automated procedure for the determination of soluble carbohydrates in herbage. J. Sci. Food Agr. 28:639-642.

Trenholm, L.E., A.E. Dudeck, J.B. Sartain, and J.L. Cisar. 1998. Bermudagrass growth, total nonstructural carbohydrate concentration, and quality as influenced by nitrogen and potassium. Crop Sci. 38:168-174.
White, L.M. 1973. Carbohydrate reserves of grasses: A review. J. Range Manage. 26:13-18.

White, R.H. and R.E. Schmidt. 1989. Bermudagrass response to chilling temperatures as influenced by iron and benzyladenine. Crop Sci. 29:768-773.

White, R.H. and R.E. Schmidt. 1990. Fall performance and post-dormancy growth of 'Midiron' bermudagrass in response to nitrogen, iron, and benzyladenine. J. Amer. Soc. Hort. Sci. 115:57-61.

Zhang, X., E.H. Ervin, and A.J. LaBranche. 2006. Metabolic defense responses of seeded bermudagrass during acclimation to freezing stress. Crop Sci. 46:25982605. 